\title{
C-N Bond forming reactions in the synthesis of substituted 2-aminoimidazole derivatives
}

\author{
Asier Gómez-SanJuan, ${ }^{a}$ José Manuel Botija, ${ }^{\text {b }}$ Almudena Méndez, ${ }^{\text {b }}$ Nuria Sotomayor, ${ }^{\text {a }}$ \\ and Esther Lete ${ }^{\mathrm{a} *}$ \\ ${ }^{a}$ Departamento de Química Orgánica II, Facultad de Ciencia y Tecnología, Universidad del \\ País Vasco / Euskal Herriko Unibertsitatea UPV/EHU, Apdo. 644, 48080 Bilbao, Spain \\ ${ }^{\mathrm{b}}$ Research and Development Department, MaxamCorp Holding, S.L., 48960 Galdakao, Bizkaia, \\ Spain \\ E-mail: esther.lete@ehu.es
}

\section{Dedicated to Professor Rosa Claramunt on the occasion of her $65^{\text {th }}$ birthday}

\begin{abstract}
Carbon-nitrogen bond forming reactions oriented to the synthesis of 2-amino-imidazolidines and imidazoles have been investigated. The C-2 amination of imidazolidinones, via the corresponding 2-chlorodihydroimidazoles, led to 2-benzylaminodihydroimidazole or bis(dihydroimidazole)amino derivatives by choosing the adequate experimental conditions. On the other hand, the use of $\mathrm{N}$-acyl-2-methylsulfanyldihydroimidazoles allowed carrying out the reactions with aromatic amines, such as $p$-anisidine. Finally, palladium catalyzed BuchwaldHartwig amination was the method of choice for $\mathrm{C}-\mathrm{N}$ coupling between 2-haloimidazoles and aromatic amines in the synthesis of the corresponding imidazoles.
\end{abstract}

Keywords: Imidazolidine, imidazole, amination, $\mathrm{C}-\mathrm{N}$ bond forming reactions

\section{Introduction}

The 2-aminoimidazole or imidazoline moieties are important structural patterns present in natural and/or synthetic products that display a broad range of biological activities. For example, Leucetta and Clathrina-derived alkaloids, which have been isolated from marine sponges during the last three decades, were reported to exhibit antibacterial, anti-inflammatory, anticancer, and antiviral activity. ${ }^{1-3}$ Different types of substituted 2-aminoimidazoles, including the pyrrole-2aminomidazoles of the oroidin family and their synthetic analogs 4,5 possess anti-biofilm activities, ${ }^{6,7}$ while 2 -arylamino or iminoimidazolidines (e.g. clonidine), known hypertensive 
agents, ${ }^{8}$ have also been evaluated as $\alpha_{2}$-adrenoceptor antagonists for the treatment of depression (Figure 1). ${ }^{9-11}$

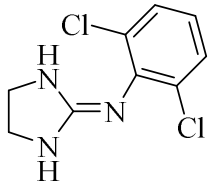

Clonidine

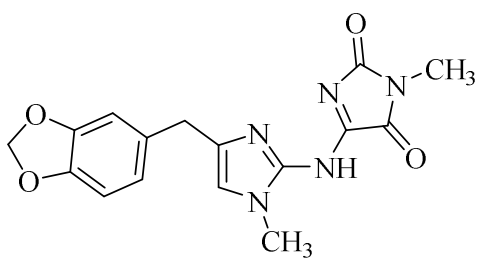

Clathridine A

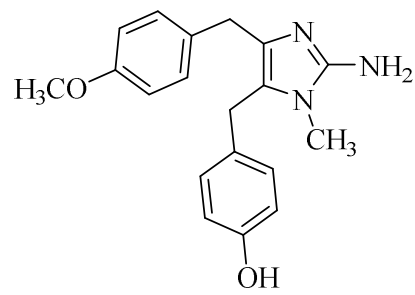

Naamine A

\section{Figure 1}

Several synthetic methods have been reported in the literature to obtain 2-aminoimidazoles that involve the construction of the heterocycle, ${ }^{1}$ including the addition of substituted guanidines $^{12,13}$ or 2 -aminopyrimidines (protected guanidines) ${ }^{14}$ to $\alpha$-haloketones, the basemediated semi cleavage of hemiaminals obtained by reaction of $N$-Boc protected guanidines and $N$-carbomethoxy-1,2-dihydropyridines, ${ }^{15}$ or the condensation of cyanamide and $\alpha$-aminoketones ${ }^{16}$ or $\alpha$-aminoesters. ${ }^{6}$ In a similar way, the corresponding 2 -aminoimidazolines have been synthesized by condensation of $N$-arylcarbonimidodithioates and ethylenediamine, ${ }^{17,18}$ and by intramolecular cyclization of functionalized arylthioureas, obtained by reaction of isothiocyanatobenzene and ethylenediamine. ${ }^{19,20}$

A different approach relies in the late-stage introduction of the 2-amino group into imidazoles or imidazolines. Thus, the imidazole ring could be lithiated at C-2, followed by reaction with azides and subsequent reduction to obtain 2-aminoimidazoles. ${ }^{21-26}$ However, this procedure requires several steps, and has failed in the synthesis of some natural products, such as kealiiquinone. ${ }^{27}$ To solve these problems, Lovely group has recently developed a convenient procedure for the direct conversion of imidazolium salts into 2-aminoimidazoles by using $N$ chloroamides at room temperature. ${ }^{27}$

On the other hand, the synthesis of biologically active imidazolines, such as clonidine and indanazoline has been developed by Cussac et al. through the condensation between primary amines and imidazolidin-2-ones or 2-methylsulfanyldihydroimidazoles. ${ }^{28-31}$ Other procedures involve the condensation of amines with dihydroimidazol-3-ium-2-sulfonate ${ }^{32}$ or with protected imidazolidine-2-thione, though the last procedure requires the use of mercury (II) chloride. ${ }^{9}$

As part of our program to develop new procedures for the synthesis of heterocyclic systems, ${ }^{33-35}$ we investigated several carbon-nitrogen bond forming reactions directed to the synthesis of 2-aminoimidazole derivatives. The aim was to achieve the amination at the C-2 position of both imidazole and imidazolidine moieties, avoiding metalation with strong (and potentially nucleophilic) bases. Thus, we studied the amination of imidazolidinones via the corresponding 2-chlorodihydroimidazoles $(\mathbf{I}, \mathrm{X}=\mathrm{Cl})$, or 2-methylsulfanylhydroimidazoles (I, 
$\left.\mathrm{X}=\mathrm{SCH}_{3}\right)$, and palladium catalyzed reactions of 2-haloimidazoles and amines $(\mathrm{I}, \mathrm{X}=\mathrm{Br})$. Further, we were interested in the application of these procedures to the synthesis of bisimidazolic systems, such as III, in one step (Figure 2).

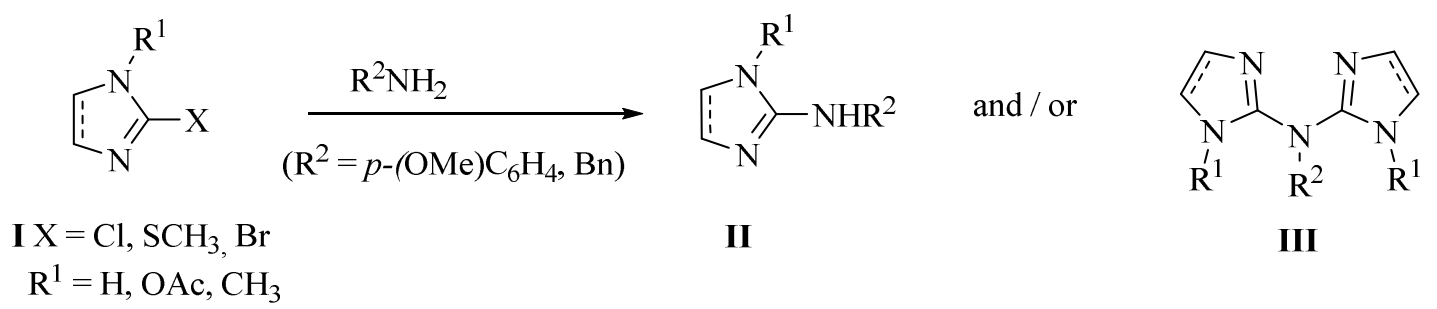

Figure 2

\section{Results and Discussion}

It is observed that a large number of bioactive alkaloids contain a central 2-aminoimidazole ring, substituted by one or two benzyl groups at various locations around the heterocyclic ring. ${ }^{2}$ Although there are no examples of $N$-benzyl azoles, it should be interesting to prepare this type of derivative in order to test structure-activity relationships. On the other hand, it is very wellknown that the presence of a 2-arylamino or imino group is an important structural key feature of pharmacophores, such as clonidine. ${ }^{8}$ For this reason, we started our study with the synthesis of 2aminoimidazolines II starting from 2-chlorodihydroimidazoles $\mathbf{I}(\mathrm{X}=\mathrm{Cl})$ or their methylthio analogue $\left(\mathrm{X}=\mathrm{SCH}_{3}\right)$ and using both benzylamine and $p$-anisidine. In this context, Cussac group has reported that 2-methylthioimidazolines can be converted into 2-iminoimidazolines by heating with primary amines. While this chemistry appears to work quite well, the alternative route of condensation of primary amines with $\mathrm{N}$-acetylimidazolidin-2-one via its 2-chloro derivative formed in situ with $\mathrm{POCl}_{3}$ only led to low to moderate yields (22-74\%) of the $N$-acetylated imino derivatives. $^{28}$

We began by using the commercially available imidazolidin-2-one (1a) as substrate. We first tried the one-pot procedure developed by Cussac and col., in which the chloride 2a is generated in situ with $\mathrm{POCl}_{3}$ in the presence of the amine. Although various reaction conditions were tested, this procedure always gave a sluggish reaction, providing a complex mixture of products. After some experimentation, we found that best results were obtained by stepwise conversion of the imidazolidin-2-one into the corresponding 2-chlorodihydroimidazole 2a. This compound has been widely used in the synthesis of diverse heterocyclic structures, ${ }^{36-38}$ and has been prepared mainly by chlorination of imidazolidine-2-thione. ${ }^{39}$ The conditions outlined in Scheme 1 were the most effective overall for the subsequent reaction of $\mathbf{2 a}$ with the primary amine to give 2aminoimidazoline $\mathbf{3}$. Thus, the 2-chloro derivative $\mathbf{2 a}$ was efficiently obtained by treatment of imidazolidin-2-one 1a with phosphorus pentachloride in acetonitrile at room temperature. The 
reaction with phosphorus oxychloride under various conditions was always sluggish. This chloride 2a was immediately reacted with benzylamine in dichloromethane as solvent and at room temperature to give 3 in $62 \%$ yield. However, an interesting point arose when we came to perform the amination using the chloride $\mathbf{2 a}$ in excess. Thus, treatment of the initially formed 2chloro derivative $\mathbf{2 a}(2 \mathrm{mmol})$ with benzylamine $(1 \mathrm{mmol})$ in dichloromethane under reflux for $21 \mathrm{~h}$ led to benzyl bis(dihydroimidazole)amine 4 (60\%). It should be pointed out that bis(2aminoimizadolines) with different linkers between the two heterocyclic rings show interesting pharmacological profiles when compare with the mono-imidazoline compounds. ${ }^{11}$ Furthermore, these compounds could be considered as bidentate nitrogen ligands in transition-metal mediated $\mathrm{C}-\mathrm{C}$ bond formation reactions. ${ }^{40}$

These conditions were tested on the $N$-acetylimidazolidinone $\mathbf{1 b}$, prepared by acetylation of the imidazolidinone 1a. ${ }^{41}$ However, all attempts using either benzylamine or $p$-anisidine always failed. Similar results were obtained when the one-step Cussac protocol was used.

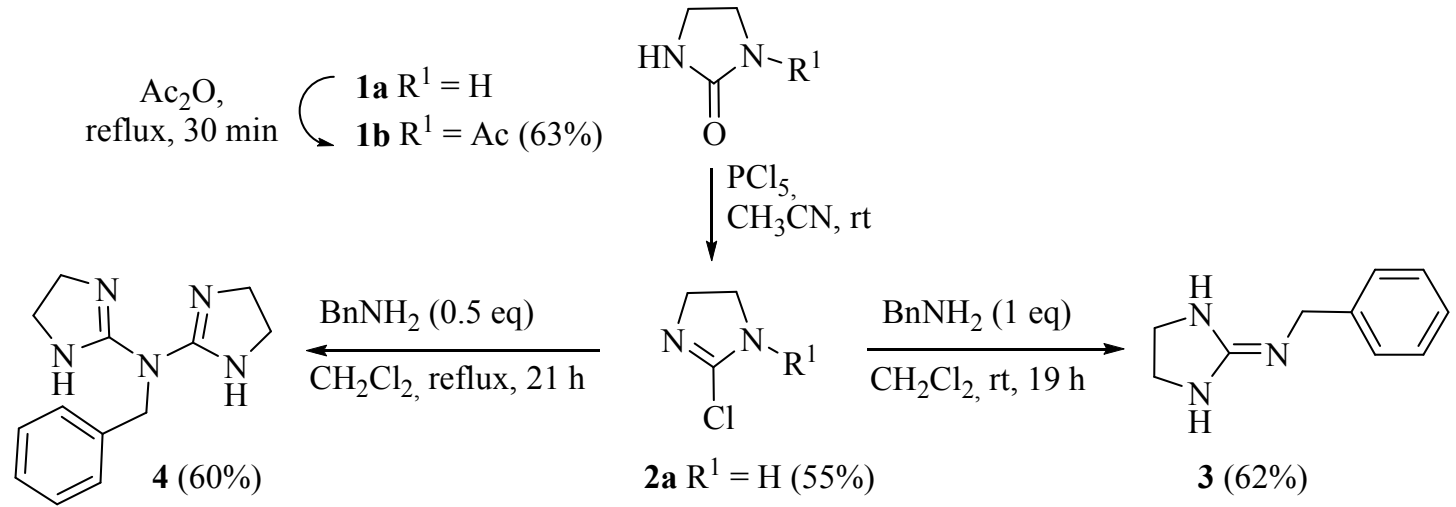

\section{Scheme 1}

When we tried to extend the procedure to the use of aromatic amines, the procedure failed. Several exploratory sets of conditions were employed to carry out this transformation either using imidazolidinone (1a) or its $N$-acetyl derivative (1b), but the results were very poor. Therefore, an alternative route involving amination of alkylthioimidazolidines was investigated. Thus, we decided to apply the procedure developed by Mundla et al. ${ }^{29}$ to the $\mathrm{N}$-acyl-2methylthioimidazolines 7a-c using $p$-anisidine.

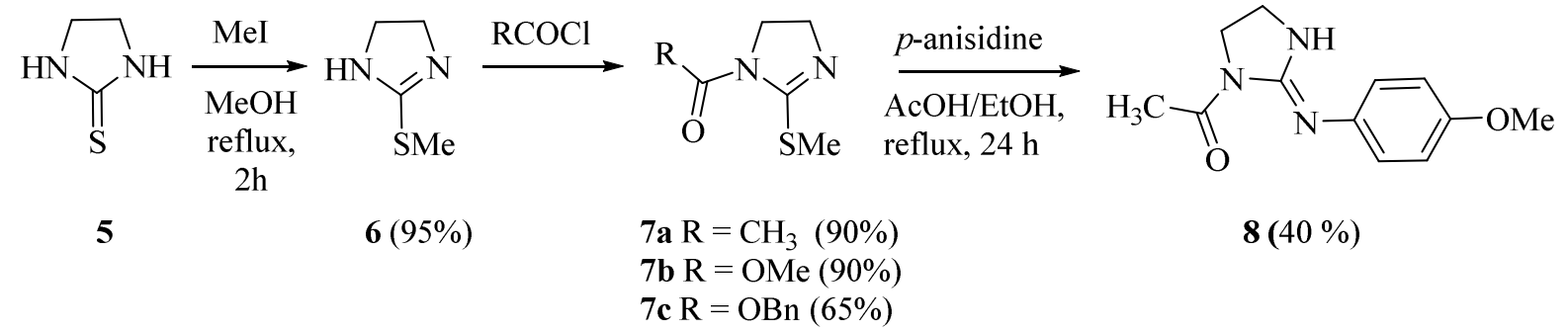

Scheme 2 
Synthesis of the target compounds $\mathbf{7 a - c}$ began with imidazolidine-2-thione $\mathbf{5}$, which was transformed into the corresponding 2-methylsulfanyldihydroimidazole $\mathbf{6}$ by treatment with methyl iodide in methanol under reflux (Scheme 2). ${ }^{42}$ Compound 6 was easily acylated with $\mathrm{Ac}_{2} \mathrm{O}, \mathrm{ClCO}_{2} \mathrm{CH}_{3}$, or $\mathrm{ClCO}_{2} \mathrm{Bn}$ under standard conditions to the corresponding $N$-acyl derivatives 7a-c in good yields.

We then undertook the C-2 amination. After some preliminary experiments on the $N$-acyl derivatives 7a-c with $p$-anisidine, we settled on using $\mathrm{N}$-acetyl derivative 7a in $\mathrm{AcOH}(10 \%) /$ EtOH under reflux (Scheme 2), which provided the 2-arylimidazoline 8 in moderate yield. With the methoxycarbonyl (7b) and benzyloxycarbonyl (7c) derivatives we observed the formation of complex mixtures of products, probably due to hydrolysis of the carbamate moiety in the acidic reaction media and other unidentified side reactions. Other solvents were used (EtOH, dioxane), but no reaction was observed under these conditions. Although the reaction of the unprotected 2methylsulfanyldihydroimidazole 6 with various primary alkyl amines has been reported, ${ }^{28}$ no reaction was obtained when $\mathbf{6}$ was treated with benzylamine or $p$-anisidine. Thus, the use of methylsulfanyl derivatives such as $\mathbf{7 a}$ allowed the amination reactions with aromatic amines under mild reaction conditions, but it required protection of the nitrogen atom of the imidazoline. However, this procedure did not allow the preparation of bis-(2-aminoimidazolines) when $7 \mathbf{a}$ was used in excess.

1D and 2D NMR experiments allowed us to determine the predominant tautomeric form of these compounds. As expected, $\mathbf{3}$ and $\mathbf{8}$ exist as the imino tautomers, whereas the bis(guanidine) derivative 4 has perforce the 2 -amino structure. In fact, the most characteristic signal for these compounds is the resonance of the quaternary carbon $\mathrm{C}-2$ in the ${ }^{13} \mathrm{C} \mathrm{NMR}$, which appears at $\delta=$ 162.0 and $160.0 \mathrm{ppm}$ for the imino tautomers $\mathbf{3}$ and $\mathbf{8}$, respectively, and at $\delta=127.7 \mathrm{ppm}$ for the 2 -amino derivative 4 . Besides, in the case of the 2 -arylamino derivative 8 , the ortho aromatic protons are substantially more shielded $(\delta 6.84, \mathrm{~d}, J 8.9 \mathrm{~Hz})$ than the meta protons $(\delta 7.10, \mathrm{~d}, J$ $8.9 \mathrm{~Hz}$ ). In an amino tautomer all aromatic protons should absorb in a narrow range (6.33-6.74 ppm). These data are in full agreement with the predicted chemical shifts and the bibliographical data. $^{30,43}$

Our next step was to replace the imidazolidine-amine unit by a 2-aminoimidazole. As stated above, introduction of the $\mathrm{NH}_{2}$ group at the $\mathrm{C}-2$ position of the imidazole ring has been carried out by a metalation/azide formation/reduction strategy, which requires a further alkylation step to provide access to the $N$-substituted derivatives. ${ }^{21-26}$ Therefore, we sought for a more direct approach for the direct introduction of an arylamino group at $\mathrm{C}-2$, which may also eliminate the use of strong bases. In this context, palladium-catalyzed amination methodologies for the formation of $\mathrm{C}-\mathrm{N}$ bonds ${ }^{44}$ were the method of choice. This procedure has been successfully applied mainly to benzo or hetero fused imidazole derivatives. Thus, the reaction of 2chlorobenzimidazoles with 4-aminopiperidine led to the preparation of the antihistaminic norastemizole, ${ }^{45}$ while a series of amide substituted purine derivatives were synthesized via palladium-catalyzed amidation reactions. ${ }^{46}$ Thus, we set out to search for an adequate catalytic 
system to achieve the $\mathrm{C}-\mathrm{N}$ coupling between $p$-anisidine and 2-bromo-1-methylimidazole (9) (Scheme 3).

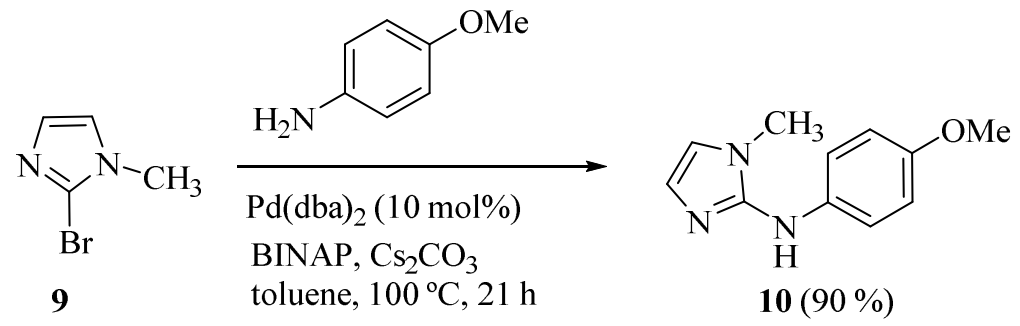

\section{Scheme 3}

Initial efforts to effect this palladium-catalyzed reaction employed the protocol developed by the Rizzo group ${ }^{47}$ for the coupling of related substrates, 8-bromodeoxyguanosine derivatives: $\operatorname{Pd}_{2}(\mathrm{dba})_{3}(10 \mathrm{~mol} \%)$ as a catalyst in the presence of BINAP (30 mol\%) with lithium hexamethyldisilazide as the base in toluene at $100{ }^{\circ} \mathrm{C}$. However, in our case, a complex mixture of products was formed, and the 2-aminoimidazole could not even be detected. A series of bases was screened in an effort to develop a cleaner reaction. Gratifyingly, on changing the base to $\mathrm{Cs}_{2} \mathrm{CO}_{3}$, the C-N coupling product, $\mathrm{N}$-aryl-1-methyl- $1 \mathrm{H}$-imidazole-2-amine (10), was obtained in very good crude yield (90\%), based on ${ }^{1} \mathrm{H}$ NMR. However, this product was unstable and could not be purified by column chromatography. Because of the aromatic nature of the imidazole ring, this compound presents the 2-arylamino structure. In particular C-2 resonates at $\delta=139.9 \mathrm{ppm}$ in ${ }^{13} \mathrm{C} \mathrm{NMR}$, while the aromatic protons meta and ortho appear at $\delta 6.67,(\mathrm{~d}, J 9.0 \mathrm{~Hz})$ and $\delta$ 6.72, (d, $J 9.0 \mathrm{~Hz}$ ), respectively. ${ }^{43}$ Decreasing the catalyst loading led to a lower yield and conversion. It should also be mentioned that attempts to apply the procedure to the 2bromoimidazole with a free $\mathrm{NH}$ group or to the corresponding 2-haloimidazolines always failed.

\section{Conclusions}

In summary, 2-benzylamino and 2-arylaminoimidazolines were prepared by C-2 amination via the corresponding 2-chlorodihydroimidazoles or 2-methylsulfanyldihydroimidazoles, respectively. The first procedure is the method of choice when primary amines, such as benzylamines, are employed and also allows the preparation of bis(dihydroimidazole)amino derivatives by choosing the adequate experimental conditions. On the other hand, the use of $\mathrm{N}$-acyl-2-methylsulfanyldihydroimidazoles allows the reactions with aromatic amines, such as $p$-anisidine, to be carried out, though it requires protection of imidazole nitrogen atom as its acetyl derivative. Finally, palladium catalyzed Buchwald-Hartwig amination allows the C-N coupling between 2haloimidazoles and aromatic amines. 


\section{Experimental Section}

General experimental methods. Melting points were determined in unsealed capillary tubes. IR spectra were obtained on $\mathrm{KBr}$ pellets (solids) or in film over $\mathrm{NaCl}$ pellets (oils). NMR spectra were recorded at $20-25{ }^{\circ} \mathrm{C}$, running at 300 or $500 \mathrm{MHz}$ for ${ }^{1} \mathrm{H}$ and 75.5 or $125.7 \mathrm{MHz}$ for ${ }^{13} \mathrm{C}$ in $\mathrm{CDCl}_{3}$ solutions, unless stated otherwise. Assignment of individual ${ }^{13} \mathrm{C}$ and ${ }^{1} \mathrm{H}$ resonances is supported by DEPT experiments and 2D experiments (COSY, HMBC, HSQC, NOESY) when necessary. Mass spectra were recorded under electron impact at $70 \mathrm{eV}$. Exact mass was obtained using a TOF detector. GC-MS analyses were performed using a TRB-1 column (methyl polysiloxane, $30 \mathrm{~m} \times 0.25 \mathrm{~mm} \times 0.25 \mu \mathrm{m}$ ). TLC was carried out with $0.2 \mathrm{~mm}$ thick silica gel plates. Visualization was accomplished by UV light. Flash column chromatography on silica gel was performed with Kieselgel 60 (230-400 mesh). All solvents used in reactions were anhydrous and purified according to standard procedures. All air- or moisture-sensitive reactions were performed under argon; the glassware was dried $\left(130^{\circ} \mathrm{C}\right)$ and purged with argon.

1-Acetylimidazolidin-2-one $(\mathbf{1 b}) .{ }^{41}$ A solution of imidazolidin-2-one $1 \mathbf{a}(0.47 \mathrm{~g}, 5.3 \mathrm{mmol})$ in $\mathrm{Ac}_{2} \mathrm{O}(4.5 \mathrm{~mL})$ was refluxed for $30 \mathrm{~min}$. The reaction mixture was allowed to cool down to room temperature, and a white precipitate was formed. The precipitate was collected by vacuum filtration, and the filtrate was concentrated in vacuo. The combined solids obtained were purified by flash column chromatography (silicagel, AcOEt) to obtain $\mathbf{1 b}$, as a white solid $(0.43 \mathrm{~g}, 63 \%)$ $\mathrm{mp}(\mathrm{EtOH}) 180-181{ }^{\circ} \mathrm{C}$ (Lit. $\left.{ }^{41} 177-178^{\circ} \mathrm{C}\right)$; IR (KBr): $v_{\max } 1654,1725,3259 \mathrm{~cm}^{-1} ;{ }^{1} \mathrm{H}$ NMR (300 MHz) $\delta 2.47(\mathrm{~s}, 3 \mathrm{H}), 3.47(\mathrm{t}, J 8.1 \mathrm{~Hz}, 2 \mathrm{H}), 3.92(\mathrm{t}, J 8.1 \mathrm{~Hz}, 2 \mathrm{H}), 5.87$ (broad s, $1 \mathrm{H}) ;{ }^{13} \mathrm{C}$ NMR $(75.5 \mathrm{MHz}) \delta 23.3,36.4,42.1,157.2,170.8$; MS (CI, $230 \mathrm{eV}) \mathrm{m} / z(\%) 129\left[\mathrm{MH}^{+}\right], 128\left[\mathrm{M}^{+}\right], 85$ (100), 70 (10).

2-Chloro-4,5-dihydro-1H-imidazole (2a). To a solution of imidazolidin-2-one $\mathbf{1 a}$ (1.61 g, 18.35 $\mathrm{mmol})$ in dry $\mathrm{CH}_{3} \mathrm{CN}(40 \mathrm{~mL}), \mathrm{PCl}_{5}(5.80 \mathrm{~g}, 27.52 \mathrm{mmol})$ was added dropwise along 10 minutes at room temperature, and the resulting mixture was stirred at this temperature for 3 days, and organic solvent was removed in vacuo. Trituration with acetone $(40 \mathrm{~mL})$ afforded 2chlorodihydroimidazole (2a) (1.06 g, $55 \%$ ) as a brown solid, which proved to be highly hygroscopic: IR (KBr): $v_{\max } 1725,3237 \mathrm{~cm}^{-1} ;{ }^{1} \mathrm{H}$ NMR (300 MHz, DMSO-d $\left.d_{6}\right) \delta 3.28(\mathrm{t}, J 7.9$ $\mathrm{Hz}, 2 \mathrm{H}), 3.70$ (t, $J 7.9 \mathrm{~Hz}, 2 \mathrm{H}), 11.8$ (broad s, 1H); ${ }^{13} \mathrm{C}$ NMR (75.5 MHz, DMSO- $\left.d_{6}\right) \delta 39.2$, 44.7, 160.2. HRMS (EI, $70 \mathrm{eV}$ ) Calcd. for $\mathrm{C}_{3} \mathrm{H}_{5} \mathrm{ClN}_{2}$ : 104.0141; found: 104.0218. Data have been reported for the hydrochloride. ${ }^{39}$

$\mathbf{N}$-(Imidazolidin-2-ylidene)benzylamine (3). To a solution of 2-chlorodihydroimidazole 2a $(0.85 \mathrm{~g}, 8.10 \mathrm{mmol})$ in dry $\mathrm{CH}_{2} \mathrm{Cl}_{2}(30 \mathrm{~mL})$, benzylamine $(0.89 \mathrm{~mL}, 8.10 \mathrm{mmol})$ was added at room temperature. After stirring the mixture at this temperature for $19 \mathrm{~h}, \mathrm{Et}_{2} \mathrm{O}(100 \mathrm{~mL})$ was added to give a brown solid. This solid was solved in $\mathrm{H}_{2} \mathrm{O}(20 \mathrm{~mL})$ and $10 \% \mathrm{NaOH}$ was added until $\mathrm{pH}$ 10. The aqueous phase was extracted with $\mathrm{CH}_{2} \mathrm{Cl}_{2}(3 \times 20 \mathrm{~mL})$. The combined organic extracts were dried $\left(\mathrm{Na}_{2} \mathrm{SO}_{4}\right)$ and concentrated in vacuo to afford $3(0.88 \mathrm{~g}, 62 \%)$ as an oil: IR (film): $v_{\max } 1666 \mathrm{~cm}^{-1} ;{ }^{1} \mathrm{H}$ NMR (300 MHz) $\delta 1.27(\mathrm{~s}, 2 \mathrm{H}), 3.87(\mathrm{~s}, 4 \mathrm{H}), 4.49(\mathrm{~s}, 2 \mathrm{H}) 7.25-7.37$ 
(m, 5H). ${ }^{13} \mathrm{C}$ NMR $(75.5 \mathrm{MHz}) \delta 29.7,53.4,127.0,128.2,128.8,143.4,162.0$. HRMS (EI, 70 eV) Calcd. for $\mathrm{C}_{10} \mathrm{H}_{13} \mathrm{~N}_{3}$ : 175.1109; found: 175.1109 .

$\boldsymbol{N}$-benzyl- $\boldsymbol{N}$-(4,5-dihydro- $1 H$-imidazol-2-yl)-4,5-dihydro- $1 H$-imidazol-2-amine (4). To a solution of 2-chlorodihydroimidazole $2 \mathbf{a}(0.93 \mathrm{~g}, 8.92 \mathrm{mmol})$ in dry $\mathrm{CH}_{2} \mathrm{Cl}_{2}(30 \mathrm{~mL})$, benzylamine $(0.48 \mathrm{~mL}, 4.46 \mathrm{mmol})$ was added at room temperature, and the reaction mixture was refluxed for $21 \mathrm{~h}$. The mixture was allowed to cool down to room temperature and then precipitated by addition of $\mathrm{Et}_{2} \mathrm{O}(100 \mathrm{~mL})$. The precipitate was collected by vacuum filtration, and the brown solid was dissolved in $\mathrm{H}_{2} \mathrm{O}(20 \mathrm{~mL})$ and $10 \% \mathrm{NaOH}$ was added until $\mathrm{pH} 10$. The aqueous phase was extracted with $\mathrm{CH}_{2} \mathrm{Cl}_{2}(3 \times 20 \mathrm{~mL})$. The combined organic extracts were dried $\left(\mathrm{Na}_{2} \mathrm{SO}_{4}\right)$ and concentrated in vacuo to afford $4(0.64 \mathrm{~g}, 60 \%)$ as an oil: IR (film): $v_{\max }$ $1655 \mathrm{~cm}^{-1}$; ${ }^{1} \mathrm{H}$ NMR (300 MHz) $\delta 2.12$ (broad s, 2H), 3.85 (s, 8H), 4.49 (s, 2H) 7.23-7.38 (m, $5 \mathrm{H}) .{ }^{13} \mathrm{C}$ NMR $(75.5 \mathrm{MHz}) \delta 46.3,53.3,126.6,127.0,127.7,128.4$, 143.2. HRMS (EI, $70 \mathrm{eV}$ ) Calcd. for $\mathrm{C}_{13} \mathrm{H}_{17} \mathrm{~N}_{5}$ : 243.1484; found: 243.1474 .

2-(Methylthio)-4,5-dihydro- $\mathbf{H}$-imidazol-1-ium iodide $(6 \cdot \mathrm{HI}){ }^{48}$ To a solution of imidazolidine-2-thione 5 (9.82 g, $94.2 \mathrm{mmol})$ in dry $\mathrm{MeOH}(20 \mathrm{~mL})$, methyl iodide $(14.70 \mathrm{~g}, 103.59$ $\mathrm{mmol}$ ) was added at room temperature, and the resulting mixture was refluxed for $2 \mathrm{~h}$. The reaction mixture was allowed to cool down to room temperature to give a white solid precipitate. $\mathrm{Et}_{2} \mathrm{O}(20 \mathrm{~mL})$ was added, and the solid was collected by vacuum filtration. The solid was crystallized from $\mathrm{MeOH}$ to afford the dihydroimidazol-2-thione $\mathbf{6} \cdot \mathrm{HI}(21.77 \mathrm{~g}, 95 \%)$ as a white solid: mp (MeOH) $143-144{ }^{\circ} \mathrm{C}$ (Lit. ${ }^{42} 142{ }^{\circ} \mathrm{C}$ ); IR (KBr): $v_{\max } 1555,3131 \mathrm{~cm}^{-1} ;{ }^{1} \mathrm{H}$ NMR (300 MHz, DMSO- $\left.d_{6}\right) \delta 2.63$ (s, 3H), 3.86 (s, 4H), 9.96 (broad s, 2H); ${ }^{13} \mathrm{C}$ NMR $(75.5 \mathrm{MHz}$, DMSO$\left.d_{6}\right) \delta$ 13.6, 45.1, 170.4; MS (CI, $\left.230 \mathrm{eV}\right) \mathrm{m} / z(\%) 117\left(\mathrm{MH}^{+}, 6\right), 116\left(\mathrm{M}^{+}, 100\right), 87$ (43), 83 (41), 74 (19), 72 (93), 59 (18).

Synthesis of $\boldsymbol{N}$-acyldihydroimidazoles 7a-c. General procedure: To a solution of $\mathbf{6}(1 \mathrm{mmol})$ in $\mathrm{ClCH}_{2} \mathrm{CH}_{2} \mathrm{Cl}(20 \mathrm{~mL})$, was added $\mathrm{Et}_{3} \mathrm{~N}(0.5 \mathrm{mmol})$. The mixture was cooled to $0{ }^{\circ} \mathrm{C}$ and the acylating agent $(1.3 \mathrm{mmol})$ was added. The resulting mixture was stirred at room temperature for $2 \mathrm{~h}$, and organic solvent was removed in vacuo. Purification by flash column chromatography (silicagel) afforded the corresponding $N$-acylimidazoles 7a-c.

1-Acetyl-2-(methylthio)-4,5-dihydro-1H-imidazole (7a) ${ }^{29}$ According to the general procedure, dihydroimidazole $6(2.08 \mathrm{~g}, 8.51 \mathrm{mmol})$ was treated with $\mathrm{Et}_{3} \mathrm{~N}(0.64 \mathrm{~mL}, 4.60 \mathrm{mmol})$ and $\mathrm{Ac}_{2} \mathrm{O}$ $(1.12 \mathrm{~mL}, 11.50 \mathrm{mmol})$. Purification by flash column chromatography (silicagel, AcOEt : $\mathrm{MeOH}$ $20 \%$ ) afforded $N$-acetyldihydroimidazole $7 \mathbf{a}(1.21 \mathrm{~g}, 90 \%)$ as a white solid: $\mathrm{mp}$ (AcOEt) 55-57 ${ }^{\circ} \mathrm{C}$; IR (KBr): $v_{\max } 1578,1672 \mathrm{~cm}^{-1} ;{ }^{1} \mathrm{H}$ NMR (300 MHz, DMSO- $\left.d_{6}\right) \delta 2.08$ (s, 3H), 2.26 (s, 3H), 3.77-3.83 (m, 2H), 3.92-3.99 (m, 2H); ${ }^{13} \mathrm{C}$ NMR (75.5 MHz, DMSO- $\left.d_{6}\right) \delta 14.7,24.0,47.7,53.7$, 158.5, 167.7; MS (CI, $230 \mathrm{eV}) \mathrm{m} / z$ (\%) $159\left(\mathrm{MH}^{+}, 2\right), 158\left(\mathrm{M}^{+}, 8\right), 143$ (100), 115 (26), 87 (29), 85 (43), 83 (52), 71 (70), 57 (81). HRMS (EI, $70 \mathrm{eV)} \mathrm{Calcd.} \mathrm{for} \mathrm{C}_{6} \mathrm{H}_{10} \mathrm{~N}_{2} \mathrm{OS}$ : 158.0514; found: 158.0513 .

1-Methoxycarbonyl-2-(methylthio)-4,5-dihydro-1H-imidazole (7b). ${ }^{49}$ According to the general procedure, dihydroimidazole $6(0.25 \mathrm{~g}, 1.02 \mathrm{mmol})$ was treated with $\mathrm{Et}_{3} \mathrm{~N}(0.08 \mathrm{~mL}, 0.55$ mmol $)$ and methyl chloroformate $(0.11 \mathrm{~mL}, 1.38 \mathrm{mmol})$. Purification by flash column 
chromatography (silicagel, AcOEt), afforded $N$-methoxycarbonyldihydroimidazole $7 \mathbf{b}(0.16 \mathrm{~g}$, $90 \%$ ) as a white solid: $\mathrm{mp}$ (AcOEt) $105-107^{\circ} \mathrm{C}$ (Lit. $\left.{ }^{49} 103-105^{\circ} \mathrm{C}\right)$; IR (KBr): $v_{\max } 1584,1713$ $\mathrm{cm}^{-1} ;{ }^{1} \mathrm{H}$ NMR $(300 \mathrm{MHz}) \delta 2.42(\mathrm{~s}, 3 \mathrm{H}), 3.80(\mathrm{~s}, 3 \mathrm{H}), 3.88-3.91(\mathrm{~m}, 4 \mathrm{H}) .{ }^{13} \mathrm{C} \mathrm{NMR}(75.5 \mathrm{MHz})$ $\delta$ 15.0, 47.3, 53.1, 53.8, 152.3, 159.5; MS (CI 230, eV,) $m / z(\%) 175\left(\mathrm{MH}^{+}\right.$9), $174\left(\mathrm{M}^{+}, 100\right)$, 115 (66), 87 (26), 72 (41), 70 (23).

1-(Benzyloxycarbonyl)-2-(methylthio)-4,5-dihydro-1H-imidazole (7c) ${ }^{50}$ According to the general procedure, dihydroimidazole $6(0.27 \mathrm{~g}, 1.13 \mathrm{mmol})$ was treated with $\mathrm{Et}_{3} \mathrm{~N}(0.09 \mathrm{~mL}, 0.61$ mmol) and benzyl chloroformate $(0.23 \mathrm{~mL}, 1.52 \mathrm{mmol})$. Purification by flash column chromatography (silicagel, $10 \%$ AcOEt/hexane) afforded $N$-benzyloxycarbonyldihydroimidazole 7c $(0.16 \mathrm{~g}, 90 \%)$ as a white solid: $\mathrm{mp}$ (AcOEt) $67-69{ }^{\circ} \mathrm{C}$ [Lit. $\left.{ }^{50} \mathrm{mp}(\mathrm{AcOEt}) 61^{\circ} \mathrm{C}\right]$; IR (KBr): $v_{\max } 1578,1713 \mathrm{~cm}^{-1} ;{ }^{1} \mathrm{H}$ NMR $(300 \mathrm{MHz}) \delta 2.41(\mathrm{~s}, 3 \mathrm{H}), 3.89(\mathrm{~s}, 4 \mathrm{H}), 5.20(\mathrm{~s}, 2 \mathrm{H}), 7.34-7.38$ $(\mathrm{m}, 5 \mathrm{H}) ;{ }^{13} \mathrm{C}$ NMR $(75.5 \mathrm{MHz}) \delta 15.0,47.4,53.7,67.8,128.3,128.4,128.6,135.5,151.7,159.5$. MS (70 eV, EI) $m / z(\%) 250\left(\mathrm{M}^{+}, 15\right), 191(11), 91$ (100).

1-(2-(4-methoxyphenylamino)-4,5-dihydro-1H-imidazol-1-yl)ethanone (8). A mixture of 7a $(0.10 \mathrm{~g}, 0.63 \mathrm{mmol})$ and $p$-anisidine $(0.08 \mathrm{~g}, 0.63 \mathrm{mmol})$ in $\mathrm{AcOH}(0.5 \mathrm{~mL}) / \mathrm{EtOH}(4.5 \mathrm{~mL})$ was heated at reflux for $24 \mathrm{~h}$. The organic solvent was removed in vacuo, afforded 8 (0.06 g, $40 \%)$ as an oil: IR (film): $v_{\max } 1666 \mathrm{~cm}^{-1} ;{ }^{1} \mathrm{H}$ NMR (300 MHz) $\delta 1.96(\mathrm{~s}, 3 \mathrm{H}), 3.68$ (broad s, $\left.5 \mathrm{H}\right), 3.77$ $(\mathrm{s}, 3 \mathrm{H}) 6.84(\mathrm{~d}, J 8.9 \mathrm{~Hz}, 2 \mathrm{H}), 7.10(\mathrm{~d}, J 8.9 \mathrm{~Hz}, 2 \mathrm{H}) ;{ }^{13} \mathrm{C} \mathrm{NMR}(75.5 \mathrm{MHz}) \delta 23.8,43.0,55.5$, 114.9, 125.4, 129.2, 158.1, 160.0, 178.9; MS (70 eV, EI) m/z (\%) $233\left(\mathrm{M}^{+},<1\right), 191$ (41), 176 (100), 134 (37), 122 (54), 69 (31). HRMS (EI, $70 \mathrm{eV)}$ Calcd. for $\mathrm{C}_{12} \mathrm{H}_{15} \mathrm{~N}_{3} \mathrm{O}_{2}$ : 233.1164; found: 233.1165 .

$\boldsymbol{N}$-(4-Methoxyphenyl)-1-methyl-1H-imidazol-2-amine (10). To a solution of 2-bromo-1methyl-1H-imidazole $(9)(0.10 \mathrm{~g}, 0.60 \mathrm{mmol})$ in dry toluene $(6 \mathrm{~mL}), p$-anisidine $(0.15 \mathrm{~g}, 1.19$ $\mathrm{mmol}), \mathrm{Pd}_{2}(\mathrm{dba})_{3}(51.02 \mathrm{mg}, 0.06 \mathrm{mmol}), \operatorname{BINAP}(0.11 \mathrm{~g}, 0.18 \mathrm{mmol})$ and $\mathrm{Cs}_{2} \mathrm{CO}_{3}(0.39 \mathrm{~g}, 1.19$ mmol) were added sequentially, and the resulting mixture was heated at $100{ }^{\circ} \mathrm{C}$ for $21 \mathrm{~h}$. The reaction was quenched by the addition of saturated $\mathrm{NaHCO}_{3}(5 \mathrm{~mL})$. The organic layer was separated and the aqueous phase was extracted with AcOEt $(3 \times 10 \mathrm{~mL})$. The combined organic extracts were washed with brine $(5 \mathrm{~mL})$, dried $\left(\mathrm{Na}_{2} \mathrm{SO}_{4}\right)$ and concentrated in vacuo, to obtain 10 $(0.11 \mathrm{~g}, 90 \%)$ as an oil. This product was unstable and could not be further purified by column chromatography: IR (film): $v_{\max } 3343 \mathrm{~cm}^{-1} ;{ }^{1} \mathrm{H}$ NMR $(300 \mathrm{MHz}) \delta 3.44$ (broad s, 1H), 3.55 (s, $3 \mathrm{H}), 3.70(\mathrm{~s}, 3 \mathrm{H}), 6.67(\mathrm{~d}, J 9.0 \mathrm{~Hz}, 2 \mathrm{H}), 6.72(\mathrm{~d}, J 9.0 \mathrm{~Hz}, 2 \mathrm{H}), 6.92(\mathrm{~d}, J 1.4 \mathrm{~Hz}, 1 \mathrm{H}), 6.97$ (d, J $1.4 \mathrm{~Hz}, 1 \mathrm{H}) ;{ }^{13} \mathrm{C}$ NMR $(75.5 \mathrm{MHz}) \delta 34.3,55.5,114.6,116.1,119.8,122.8,129.5,139.9,152.5$.

\section{Acknowledgements}

We wish to thank the Ministerio de Ciencia e Innovación (CTQ2009-07733) and Universidad del País Vasco / Euskal Herriko Unibertsitatea UPV/EHU (UFI11/22, GIU 09/46) for their financial support. This work was performed in part under contract with MaxamCorp Holding, S.L. Technical and human support provided by Servicios Generales de Investigación SGIker 
(UPV/EHU, MICINN, GV/EJ, ERDF and ESF) is gratefully acknowledged. We also thank UPV/EHU for a postdoctoral grant (A.G).

\section{References}

1. Sullivan, J. D.; Giles, R. L.; Looper, R. E. Curr. Bioact. Comp. 2009, 5, 39. http://dx.doi.org/10.2174/157340709787580892

2. Koswatta, P. B.; Lovely, C. J. Nat. Prod. Rep. 2011, 28, 511. http://dx.doi.org/10.1039/c0np00001a PMid:20981389

3. Kumar, R.; Khan, Sh.; Chauhan, P. M. S. Curr. Drug. Targ. 2011, 12, 1689. http://dx.doi.org/10.2174/138945011798109428 PMid:21561428

4. Forte, B.; Malgesini, B.; Piutti, C.; Quartieri, F.; Scolaro, A.; Papeo, G. Mar. Drugs 2009, 7, 705. http://dx.doi.org/10.3390/md7040705

5. Al-Mourabit, A.; Zancanella, M. A.; Tilvi, S.; Romo, D. Nat. Prod. Rep. 2011, 28, 1229. http://dx.doi.org/10.1039/c0np00013b PMid:21556392

6. Rogers, S. A.; Melander, C. Angew. Chem. Int. Ed. 2008, 47, 5229. http://dx.doi.org/10.1002/anie.200800862 PMid:18528836

7. Rogers, S. A.; Lindsey, E. A.; Whitehead, D. C.; Mullikin, T.; Melander, C. Biorg. Med. Chem. Lett. 2011, 21, 1257. http://dx.doi.org/10.1016/j.bmcl.2010.12.057 PMid:21251823

8. Remko, M.; Swart, M.; Bickelhaupt, F. M. Bioorg. Med. Chem. 2006, 14, 1715. http://dx.doi.org/10.1016/j.bmc.2005.10.020 PMid:16263295

9. Dardonville, C.; Goya, P.; Rozas, I.; Alsasua, A.; Martín, M. I.; Borrego, M. J. Bioorg. Med. Chem. 2000, 8, 1567. http://dx.doi.org/10.1016/S0968-0896(00)00089-4

10. Dardonville, C.; Rozas, I.; Callado, L. F.; Meana, J. J. Bioorg. Med. Chem. 2002, 10, 1525. http://dx.doi.org/10.1016/S0968-0896(01)00420-5

11. Rodríguez, F.; Rozas, I.; Ortega, J. E.; Meana, J. J.; Callado, L. F. J. Med. Chem. 2007, 50, 4516. http://dx.doi.org/10.1021/jm070229q PMid:17691718

12. Little, T. L.; Webber, S. E. J. Org. Chem. 1994, 59, 7299. http://dx.doi.org/10.1021/jo00103a021

13. Ando, N.; Terashima, S. Synlett 2006, 2836. http://dx.doi.org/10.1055/s-2006-950250

14. Ermolat'ev, D. S.; Babaev, E. V.; Van der Eycken, E. V. Org. Lett. 2006, 8, 5781. http://dx.doi.org/10.1021/o1062421c 
15. Abou-Jneid, R.; Ghoulami, S.; Martin, M.-T.; Dau, E. T. H.; Travert, N.; Al-Mourabit; A. Org. Lett. 2004, 6, 3933. http://dx.doi.org/10.1021/o1048529e PMid:15496067

16. Aberle, N. S.; Lessene, G.; Watson, K. G. Org. Lett. 2006, 8, 419. http://dx.doi.org/10.1021/o1052568o PMid:16435849

17. Servi, S.; Genc, M.; Gür, S.; Koca, M. Eur. J. Med. Chem. 2005, 40, 687. http://dx.doi.org/10.1016/j.ejmech.2005.02.002 PMid:15935903

18. Genc, M.; Servi, S. Heteroatom Chem. 2005, 16, 142. http://dx.doi.org/10.1002/hc.20081

19. Parikh, V.; Welch, W. M.; Schmidt, A. W. Bioorg. Med. Chem Lett. 2003, 13, 269. http://dx.doi.org/10.1016/S0960-894X(02)00925-3

20. Mascaraque, A.; Nieto, L.; Dardonville, C. Tetrahedron Lett. 2008, 49, 4571. http://dx.doi.org/10.1016/j.tetlet.2008.05.098

21. Kawasaki, I.; Taguchi, N.; Yoneda, Y.; Yamashita, M.; Ohta, S. Heterocycles 1996, 43, 1375. http://dx.doi.org/10.3987/COM-96-7475

22. Danios-Zegal, S., Al-Mourabit, A., Ahond, A., Poupat, C., Potier, P. Tetrahedron 1997, 53, 7605. http://dx.doi.org/10.1016/S0040-4020(97)00452-3

23. Lindel, T.; Hochguertel, M. J. Org. Chem. 2000, 65, 2806. http://dx.doi.org/10.1021/jo991395b

24. Kawasaki, I.; Sakaguchi, N.; Khadeer, A.; Yamashita, M.; Ohta, S. Tetrahedron 2006, 62, 10182. http://dx.doi.org/10.1016/j.tet.2006.08.027

25. Jacobi, N.; Lindel, T. Eur. J. Org. Chem. 2010, 5415. http://dx.doi.org/10.1002/ejoc.201000625

26. Koswatta, P.; Lovely, C. J. Chem. Commun. 2010, 46, 2148. http://dx.doi.org/10.1039/b926285g PMid:20221521

27. Lima, H. M.; Lovely, C. J. Org. Lett. 2011, 13, 5736. http://dx.doi.org/10.1021/ol2022438 PMid:21992702 PMCid:3357904

28. Chang-Fong, J.; Benamour, K.; Szymonski, B.; Thomasson, F.; Morand, J.; Cussac, M. Chem. Pharm. Bull. 2000, 48, 729. http://dx.doi.org/10.1248/cpb.48.729

29. Mundla, S. R.; Wilson, L. J.; Klopfenstein, S. R.; Seibel, W. L.; Nikolaides, N. N. Tetrahedron Lett. 2000, 41, 6563. http://dx.doi.org/10.1016/S0040-4039(00)01102-3

30. Isobe, T.; Fukuda, K.; Ishikawa, T. J. Org. Chem. 2000, 65, 7770. http://dx.doi.org/10.1021/jo000744v

31. Ryoda, A.; Yajima, N.; Haga, T.; Kumamoto, T.; Nakanishi, W.; Kawahata, M.; Yamaguchi, K.; Ishikawa, T. J. Org. Chem. 2008, 73, 133. http://dx.doi.org/10.1021/jo701923z PMid:18062699 
32. Muche, M.-S.; Göbel, M. W. Angew. Chem Int. Ed. 1996, 35, 2126. http://dx.doi.org/10.1002/anie.199621261

33. Gómez-SanJuan, A.; Sotomayor, N.; Lete, E. Beilstein J. Org. Chem. 2013, 9, 313. http://dx.doi.org/10.3762/bjoc.9.36 PMid:23504613 PMCid:3596099

34. Martínez-Estíbalez, U.; Gómez-SanJuan, A.; García-Calvo, O.; Aranzamendi, E.; Lete, E.; Sotomayor, N. Eur. J. Org. Chem. 2011, 3610. http://dx.doi.org/10.1002/ejoc.201100123

35. Lage, S.; Martínez-Estíbalez, U.; Sotomayor, N.; Lete, E. Adv. Synth. Catal. 2009, 351, 2460 . http://dx.doi.org/10.1002/adsc.200900368

36. Saczewski, F.; Saczewski, J. Trends Heterocycl. Chem. 2003, 9, 19, and references therein.

37. Saczewski, F.; Kornicka, A.; Gdaniec, M.; Halasa, R.; Werel, W. Eur. J. Org. Chem. 2004, 3511, and references therein.

http://dx.doi.org/10.1002/ejoc.200400229

38. Wasilewska, A.; Saczewski, F.; Gdaniec, M.; Makowska, A.; Bednarski, P. J. Arkivoc, 2011, 160.

http://dx.doi.org/10.3998/ark.5550190.0012.a14

39. Trani, A.; Bellasio, E. J. Heterocycl. Chem. 1974, 11, 257. http://dx.doi.org/10.1002/jhet.5570110232

40. Aoki, M.; Kaneko, M.; Izumi, S.; Ukai, K.; Iwasawa, N. Chem. Commun. 2004, 2568. http://dx.doi.org/10.1039/b411802b PMid:15543283

41. Bach, T.; Aechtner, T.; Neumüller, B. Chem. Eur. J. 2002, 8, 2464. http://dx.doi.org/10.1002/1521-3765(20020603)8:11<2464::AID-CHEM2464>3.0.CO;2-S

42. Aspinall, S. R.; Bianco, E. J. J. Am. Chem. Soc. 1951, 73, 602. http://dx.doi.org/10.1021/ja01146a030

43. Jackman, L. M.; Jen, T. J. Am. Chem. Soc. 1975, 97, 2811. http://dx.doi.org/10.1021/ja00843a033

44. Lundgren, R. J.; Stradiotto, M. Aldrichimica Acta 2012, 45, 59.

45. Hong, Y.; Tanoury, G. J.; Wilkinson, H. S.; Bakale, R. P.; Wald, S. A.; Senanayake, C.H. Tetrahedron Lett. 1997, 38, 5607. http://dx.doi.org/10.1016/S0040-4039(97)01273-2

46. Li, X.; Vince, R. Bioorg. Med. Chem. 2006, 14, 5742. http://dx.doi.org/10.1016/j.bmc.2006.04.011 PMid:16753300

47. Elmquist, C. E.; Stover, J. S.; Wang, Z.; Rizzo, C. J. J. Am. Chem. Soc. 2004, 126, 11189. http://dx.doi.org/10.1021/ja0487022 PMid:15355100 
48. Denk, M. K.; Ye, X. Tetrahedron Lett. 2005, 46, 7597.

http://dx.doi.org/10.1016/j.tetlet.2005.08.150

49. Smejkal, T.; Gribkov, D.; Geier, J.; Keller, M.; Breit, M. Chem. Eur. J. 2010, 16, 2470. http://dx.doi.org/10.1002/chem.200902553 PMid:20077538

50. Dixon, J.; Brennan, C.; Dumas, J.; Hatoum-Mokdad, H.; Sibley, R.; Hart, B.; Khire, U.; Scott, W. J.; Johson, J.; Liu, P.; Redman, A.; Wood, J. PCT Int. Appl. WO 2003059872 A1, 2003; Chem. Abstr. 2003, 139, 133343. 